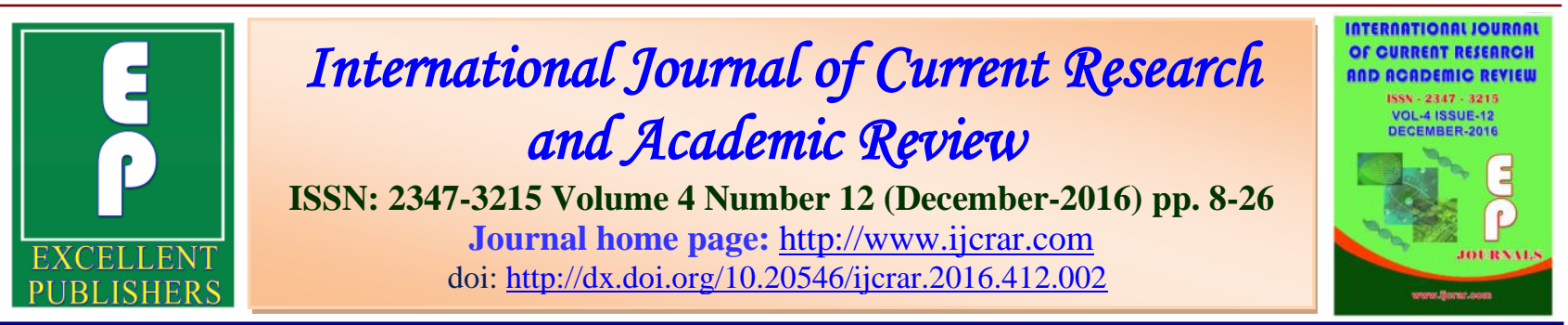

\title{
Digitisation of Payments - A Step towards Digital India Movement
}

\section{Smrithi Baiju and Radhakumari Challa*}

Department of Management and Commerce, Sri Sathya Sai Institute of Higher Learning, Puttaparthy, Anantapur Dist. Anantapur, Andhra Pradesh, India

\section{*Corresponding author}

\begin{tabular}{l|l}
\hline \multirow{2}{*}{$\begin{array}{l}\text { KEYWORDS India, } \\
\text { Digitisation of } \\
\text { Payments. }\end{array}$} & $\begin{array}{l}\text { A B S T R A C T } \\
\text { Digitalization means using digital technology as a part of everyday life. } \\
\text { Digitization of payments helps a person to transfer money from his bank } \\
\text { account to the payees for his day to day transactions. Modes of digital } \\
\text { payments include a number of instruments under one umbrella which can be } \\
\text { used as and when required. India is stepping in to the leadership role in the } \\
\text { arena of internet age and is anticipating a growth in such a way people have } \\
\text { more access to mobile than that of electricity connections at home. Thus India } \\
\text { is moving forward to the aim of "Cash less Society" which means paper } \\
\text { currency in circulation will reduce to minimal and all payments are made } \\
\text { through digital mechanism. The present study represents an added } \\
\text { contribution to the currently on going researches that are being done to decide } \\
\text { whether digitization is important for the nation in the current economic } \\
\text { situation. The study reaffirms that the importance of mobile penetration } \\
\text { supported by the government initiatives constitute the most important drivers } \\
\text { to enable people to move towards digital payment system. }\end{array}$
\end{tabular}

\section{Introduction}

Digitalization means using digital technology as a part of everyday life. Digitalization is different from digitization which means "the action or process of digitizing; the conversion of analogue data into digital form." Digitalization includes digitization and digitization is the first and foremost step to digitalization. Digitization of payments helps a person to transfer money from his bank account to the payees for his day to day transactions. Digital payments are a number of instruments under one umbrella which can be used as and when required. The word "digital cash "has been introduced long back but it didn't gain much attention as E-Commerce has received. The payment system has gained significance once the countries which are into digitization proved to be more effective in financial inclusion measures. India is stepping in to the leadership role in case of internet stage, as it is dominating many other countries like US in case of internet usage and anticipating a growth in such a way 
people have more access to mobile than that of electricity connections at home. Indian policies are changing to adapt to the new digital world. India is open to innovation and are expecting a large investment in Indian E-commerce industry. Even though internet comes with many disadvantages India is trying to use its maximum benefits in order to create transparency in the system and that is one of the reason why Government shifted towards E-governance.

With these initiatives government is trying to create a sense of safety in using internet among those who really feel unsecured in using digital space. Most of the government sites are equipped to accept card payments and net banking. There will be need for the businesses as well as financial institutions to innovate themselves as government moving towards the digitization. There are many firms which use technology to provide financial services and these companies are called as FinTech companies. They are the major digital players in the economy. With the development of such FinTech companies India has a greater scope of digitization. Ecommerce also emerged as a tool for digitization in the country. The buying behaviour of the people are greatly influenced by these firms as people can make informed decisions anytime anywhere.

Digitization of payment system is the foremost step towards "Digital India and the policies and initiatives under the scheme helps to build necessary infrastructure for digitization. Thus India is moving forward to the aim of "Cash less Society" which means paper currency in circulation will reduce to minimal and all payments are made through digital payment system.

The present study is also a contribution towards the researches that are being done in order to decide whether digitization is important for the nation in the current economic situation and the enablers of this movement of India is also discussed. The study reaffirms that the importance of mobile penetration supported by the government initiatives constitute the most important drivers to enable people to move towards a digital payment system.

\section{Literature Study}

Digitization has been viewed as one of the major tool for financial inclusion by many of the countries. One such country is Nigeria which has minimal rates of financial inclusion. All the G2P payments are made through bank accounts and government accepts fees and fines electronically. The report on digitizing government payments in Nigeria states "Digitization of social benefit programs would reduce leakage from corruption and fraud and ensure government payments reach beneficiaries on time and in full, due to reduced delivery costs. It is estimated that leakage in the administration of social benefit programs could be as high as US\$60-80 million."(Bill \& Melinda Gates Foundation, 2014)Digitization is seen as vital in order to achieve G20 goals too. In 2010 G20 authorized Principles for Innovative Financial Inclusion which stated that the extensive adoption of digital payments for international and domestic remittances can be influential in reaching the goals of the G20 i.e. financial inclusion. The report says that there are many benefits for the government such as transparency in the system, control corruption to some extend and lower cost as to transferring social benefits, printing currency etc. As per the G20 report " broader adoption of digital payments - with regard to both remittances and other payments - can significantly advance the global financial inclusion agenda and support the priority areas of the Global Partnership for Financial Inclusion 
(GPFI)." (World Bank Development Research Group, the Better Than Cash Alliance, and the Bill \& Melinda Gates Foundation, 2014)

India is also focusing on the digitization of payment system with a view to become Digital India in all aspects of functioning. The main aim of the country is to reduce the value of currency in circulation which is greater than of any emerging markets. "Government subsidies alone comprise for estimated cash transactions worth Rs. 2.93 trillion." India should build infrastructure to support the digital transactions as well as spread digital literacy in order to digitize its payment system. (Singh, 2015). The government initiatives were started with the last budget to make digital cash usage within the economy. Cash has its own risk attached with it, chance of getting misused and thoroughly promotes black money still it has acceptability across the world. In cash heavy society like India in order to promote digital money government needs to bring about equivalence between the two (Surya, 2016)

The access to digital money can be made only through building infrastructure. The mobile internet penetration in India can be used as a tool in order to digitalize the payments. The study conducted by YourStory.com, in collaboration with Nasscom and Akamai projected a future internet report stating there will be nearly

- 730 million Internet users:

- $75 \%$ of new Internet user growth from rural areas ;

- $70 \%$ of E-Commerce transactions via mobile phones;

According to the study in the coming years mobile will be the tool for reaching out to every part of the nation. (NASSCOM AKAMAI TECHNOLOGIES, 2016) The World Bank estimates that the rise in broadband connections by $10 \%$ leading to an increase in economic growth of 1.38 percentage in the middle and lower income countries. The access to internet should be considered as basic necessity as it will enable access to employment, education and other social and economic growth (The Internet and Mobile Association of India, 2014-15). The studies show that the economic benefit of digital finance is more that it will have an impact of standard of living as well as quality of human capital. In one of the studies it found that absenteeism is more in case of states which do not follow a digital payment system for disbursement of salary while it is only $90 \%$ in those states which has a digital system (McKinsey Global Institute, 2016).

Technology always made human life easier. Electronic payment system is also to enable smooth and hassle free payment system which is efficient, reliable and affordable. Payment system is backbone of any country and India need to make such decisions carefully and intelligently to make digitization its strength to grow stable (Kaur \& Kaur, 2015).

\section{Need and significance of study}

Governments are the major originator of payments and digitization helps government to be more efficient, transparent in distributing benefits to the citizens of the nation. Digitization in general helps a nation to have savings in cost, helps in tracing financial flows and widen the revenue base. The transaction cost dropped from 14.7 percent to 2.6 percent in Brazil after bundling many services under one payment card. The payment of bribe to local officials has reduced from 3.6 percent to 0.3 percent 
in Argentine when they adopted digitization. Thus countries around the world has benefited from digitization of payment system.

Indian government is also having a vision to digitize the payment system of the nation. Indian government first launched "PradhanMantri Jan-DhanYojana "on August 28, 2014 in order to facilitate the nation to open bank accounts and promote financial inclusion. The "Digital India" program is another pillar which is largest digitization programs with four core areas of the program that is:

Rural Broadband for All

Universal Mobile Access

Wi-Fi in Varsities

Public Wi-Fi Hotspots

The next step was to introduce Unified Payment Interface (UPI), which permit individuals to make payments using single identifier like virtual addressor Aadhaar number. Another effort from Government was the launch of the Bharat Bill Payment System (BBPS) in September 2016; to promote digital payments in the nation. Thus government is focusing on digitizing the payments for the overall development of the nation. The Government leaders and the people of the nation really recognize the impact digitization will have on India and its citizens, and how it will lead to economic growth and innovation.

This paper studies the factors that are leading to digitization in the nation as well as the programs and initiatives taken by Indian government to promote the same. The paper also dwells into the importance of adopting and adapting to digital cash and the various challenges faced by government as well as the customers in such a system.

The main objectives of this study includes, Digitization is one of the main initiatives by the central government. To highlight the factors that is enabling the digitization of payment system in the country. To analyze the importance of digital payment system for the Indian economy. And also to understand the possible challenges that can be faced by the government as well as the people in using such a system.

\section{Data sources}

The study is based on Secondary data available. The concept of digitization is very novel and therefore the study has focused on the secondary data such as research papers, budget report, news paper articles.

\section{Research Design}

The research design followed for the current paper has been depicted in the following figure 1:

\section{Methodology}

The methodology followed for achieving the objectives set for the paper is described below:

To achieve the first objective of highlighting the factors that enable the digitization of payment system in the country, a software titled "MAXQDA 12" was used. This software is data analysis software which facilitates analysis of qualitative data. Using this software the researcher can categorize the data according to previous knowledge or existing theories or some research results available. The data is categorized, coded and organised in a systematic manner. 
MAXQDA helps the user to apply many codes and categorise as many sections as possible. The coding can be done for entire paragraph or for sentences and is very useful for general topics which need sub-categories within segments. With the help of the software researcher can do content analysis and draw inferences about the respective data. This software provides memo system and it is distinct from other softwares. Another feature of this software is the documents and reports can be exported to other format like RTF, HTML or XLS which helps to reduce the tedious job of researcher. Auto arranging allows customization and segregation of elements of work. It is really easy to learn and work with the software and allows the user to colour the codes which systematically retrieve and filter data. Visual tools help the user to create more user friendly outcome.

In the current study the documents are first imported into the software using the "Import documents" option and then analysed using the tools available with the software

This process is followed by loading each document into the software for further analysis and coding. This study considers the following parameters for analysis.

Enablers of digital cash

Importance of digital cash

Challenges of Digital Cash

The picture below depicts the procedure followed for coding the data gathered from different data sources.

The Enablers were recognized as Smartphone penetration, Government support and FinTech companies out of which Government support further had subdivisions.
The study further focused what are the government initiatives that can help India move towards digitization and the program and policies which focus for the same are categorized under different groups. Thus the various policies which are influencing are clubbed under different head and the policies which are most influential are recognized.

This study has analysed 30 articles relating digitization of payment system in the nation. The articles analysed includes newspaper articles, research papers, Union Financial Budget 2016, Memos that are forwarded by the Government etc. Once the coding has been done the visual tools has been used in order to find which factor is more important.

Using the option "Statistics of sub-codes" the software gives the graphical representation of the data. For example, there are certain factors which enable or promote digital transaction in the country. This study analysed those factors from various articles and government reports to organise the data and find the factor which is more prominent in helping digitization of payment system. The graphical representation of the factors will help the users of the data to comprehend it easily.

Finally, the picture below represents the articles analysed and conveys that the smart phone usage and the internet penetration in India can act as the main enablers for digitization of payment.

Making use of the same data sources, the factors reflecting the importance of digital cash for an economy in general and with special reference to Indian economy, are identified and highlighted. Finally the understanding and the insight gained during the above process led to bringing to focus, of the possible challenges that can be faced 
by the government as well as people, in promoting the use of digital cash which is the third objective of the study.

\section{Data Analysis and interpretation}

Smartphone's are really playing smart in the Indian economy as we can see the increase in the number of Smartphone users are rapidly growing in the country. Smartphone penetrated in to the rural India $t$ at a faster pace than any other technology could in the past. These Smartphone's are becoming the main mode to access internet in the rural as well as urban area. In one of the studies recently done by Boston Consultancy Group, it was revealed that nearly 40 million Indians are using internet and nearly 40-45 hours they are spending per month. And they have also predicted that the internet users in India will be reaching half a billion within 2 years from now, which is depicted in the figure below:

One of the main reason for increasing internet users in India is due to the smartphone penetration. And the country's internet consumption has exceeded that of U.S.A to become second users globally.The availability of reasonably priced smartphones and tablets increased their penetration into the rural economy. This has helped the rural economy too transform into internet economy to a large extend. Many telecom operators are also providing high speed internet services at an affordable price to the rural population.

According to the analysis Smartphone evolved as one of the main enablers for digitalization of payments in India. Smartphones are well equiped with powerful processors, high end technologies which enable consumers to download and use necessary applications which can facilitate a particular service. Example : when a consumer wants to use Paytm to recharge his or her mobile it is very convienient for him or her to use the paytm app which is available in almost all software platforms than loading the website and then taking the service.The growth of these phones are creating new payment capabilities. The tech savvy population is shifting towards their smartphone to use debit card, credit card, net banking and digital wallet which can be used anytime and any where. The payment banks are using mobile as the main platform to reach the consumers. The "mobile wallets" has evolved due to the smartphone penetration which can be used as another means to digitilize payments. The mobile penetration paves way for the Fintech companies to evolve and help the country in digitization. The enablers which are described above are depited in Figure 3:

Another enabler of digitization of payment in India is "Fintech Companies". The change in the payment system can be due to the existence of theswe companies. Fintech companies has got the wave of change in the payment system of the country. E-commerce changed the buying pattern of the indian consumers as they started using internet for informed buying decisions and it contributed to the growing GDP of the country as well. In the same case companies like Mobikwik,Freecharge, Paytm etc are changing the face of payment system.

There are few emerging countries like Sweden,Denmark and all which are with the aim to digitize payment system had already adopted fintech revolution. And positive modernization is necessary for such growth in any nation. Many fintech companies are working towards the government goal of financial inclusion and digitization within the scope of their work. Example: one of the fintech company is Eko Financial Solutions which is a bussiness 
correspondent and partnered with SBI nad two other private banks in the country. It helps migrant indians working in different part of the nation to remit their money to their families through mobile. Paytm is another company which gives "wallet" service which can be availed by consumers and can be used to redeem from it for various online purchases.

Digitization of payment is not possible without governemnt support. Another enabler for digitization of payment is Government policies and programs. The central government has taken step by step program to enable the digital payment system in the country. Under the Jan Dhan Yojna program, government promoted opening bank account for all the citizens in India. Then it linked the bank account and all other necesarry documents with the Aadhaar which was anotther initiative by central government to promote inclusion. The "Unified Payment Interface" which helps customers to transfer money from one bank account to another using their smartphones. With the "Digital India " program which is one of the main project of Indian government can also help the digitization of payment a reality. It includes an initiative namely Bharat Net, a high speed digital highway to connect all 2.5 lakh Gram Panchayats of country. This is world's largest broadband connectivity mission. In order to help the consumers use more of digital payment system the central government and RBI has initiated many policy changes.

The measures taken by Government involve programs to build more infrastructures such as mobile POS terminal to accept more card payments; make a unified USSD platform which can support all payment mechanism; to make all government payments digital; launch Bharath Bill Pay system to make bill payments digitalize and thus India has already started investing in infrastructure which will promote digital payment system. Digital India as well as smart city plans is the road way to promote digital infrastructure in the country.

The Department of Electronics and Information Technology is also working towards the formulation of plans that can ensure Government Departments will be equipped with necessary infrastructure to accept digital payments and assist payments of fees, fines etc. through cards beyond a threshold limit through 'PayGov India'.

Department of Financial Services/ RBI facilitates that each account holder under PMJDY scheme will be provided access to the digital financial services. RBI is also planning to limit the cash transactions up to a limit and developing a methodology to enable card transactions for higher value transactions. Ministry Of Finance proposed that it will withdraw the entire surcharge relating online payments for availing Government services.RBI will be reviewing the rules relating various payment schemes and will reinforce the existing payment system in order to inspire electronic payments by all the segments of the society. RBI has also released a document "Vision 2018" during the month of June 2016 which clearly states that the body will encourage electronic payments in the nation.

In general the measures taken by the government to promote digital cash as analysed by the chosen software are portrayed below:

During the year RBI has given sanction to 11 companies for beginning Payment bank services in India. These companies include Aditya Birla, Reliance Industries, Nuvo, Paytm, Vodafone, and Airtel. For companies 
like Vodafone and Airtel this will help them to penetrate more into rural areas.RBI approval helps to build large customer base and companies like Paytm can help the government in digitization as it has over 100 million mobile wallet users which is two fold of Visa and Maestro diffusion together. The Indian government is supporting the Fintech companies in the country like Paytm in order to facilitate digitization. These FinTechs are providing a base to the pyramid of cashless payment system. In the recent scenario of banning 500 and 1000 rupee notes on November $8^{\text {th }} 2016$ the tech entrepreneur in India were motivated as they gained lot consumers in a day or two. Paytm app download went up by three times as well as payments for offline transactions by five times in the first two days after the ban.There was an increase of 1000 percent money added to the wallet within hours of announcement. These FinTech players get a large support from government as both the entities are moving towards a common goal of "digitization of payment system".

The government has taken three initiatives to promote digital payment system in India. They include bringing about the required changes to existing policy structure, increasing awareness among the citizens about the benefits of digital payment system, and enhancing the security measures in the cyber space. These are shown in the figure 4 below as an outcome of the analysis.

Department of Economic Affairs is also planning to review regulatory mechanisms under the Payments and Settlement Systems (PSS) Act, 2007 in order to facilitate digital payments. The department also introduced a single window system in order to accept all types of payments for Government Receipts. Department also proposes to introduce tax rebates or incentives on using digital payment system.
In case of promoting of payments through cards and digital means central government has voiced its support to all states of the nation repeatedly. In Andhra Pradesh NREGA wages and SSP pensions are paid through bank accounts or post office savings account. This will further promote the use of bank accounts and card payments in the state. One of the initiatives is Direct Benefit Transfer by Central Government in order to digitize payments at a massive rate. Central government has already redrafted many policies and awareness program are on rise. Depositor Education and Awareness Fund (DEAF) has been created to expand infrastructure facilities as well as to conduct awareness campaign towards a less cash society. There are measures taken to create required assurance mechanism for deceitful transaction, the money will be credited back to customers' account within reasonable time. The government also changed many of the policies so that there will not be much entry barrier for the digital wallet players as well as pre-paid instruments in the nation. The service fee or surcharge on customers who choose to make card payments for essential commodities like petrol pumps, IRCTC, tax department, etc. has been removed recently. The main policy changes that have been brought into effect by the government are depicted in the following figure:

With the help of Digital India program government is building a strong infrastructure for the nation. The program includes Broadband for rural as well as urban areas and informational infrastructure for all. As per the program the impact will be 2.5 villages will have broadband connection and 400000 public Internet Access Points.It also coversWi-Fi in 2.5 lakh schools, all universities and also public Wi-Fi for public citizens. Thus the government has already started programs to 
Int.J.Curr.Res.Aca.Rev.2016; 4(12): 8-26

build infrastructure for digitization of payments.

\section{Importance of digitization}

The Indian economy found digital cash useful as it doesn't need much of an individual's time. It is most convenient in comparison to physical cash. From an individual's point of view, he needn't stand in long queues to fill forms to withdraw money, he needn't take an off from his daily schedule to purchase the goods he wants to buy since online shopping can be done anytime anywhere which is the essence of immediacy and ubiquity. Among the digital payment options people consider digital wallet as one among the most convenient as it is hassle free mode unlike net banking where lot browsers will be open and more time consuming. Another important factor is that digital cash is more easily transferable as many migrants within India found sending money through mobile is more convenient and inexpensive than many other informal channels which they normally use. Transparency is another important factor as digitization will enable recording of each and every transaction an individual makes. It overcomes the problems which are brought about by the cash dominance i.e. large unorganised sectors, black money, evasion of taxes etc. it also helps gradually in financial inclusion as government is promoting payment of subsidies and other benefits through bank accounts. Transparency in the system will surely reduce the money laundering and increase tax compliance it leave a strong data track.

India is a country with cash to GDP ratio is $12 \%$ which states that economy is still cash intensive and three to four times than other comparable economies. This is the accounted amount of money in circulation where there are black money in circulation which is unaccounted and one of the main treason for inflation in the nation. And RBI spent nearly 21000 crore INR in operating currency in the country. The cost of printing currency is really high which is nearly INR 32 billion and a large volume of money Government spend on the same. When the nation shifts to digitization Government can lower the cost on financial inclusion measures and other programs as economy has accepted the digital payment system and in order to avail the same people need to have a bank account. The unbanked starts to shift to mobile payments and mobile wallets they will automatically be banked and will have a transaction history and further this will lead to accessibility of digital resources for all. When India wants to become digital, it has to digitize its payment system too. Thus digital India program contribute to digitization as well as digitization contributes India to become more digitally literate and tech savvy nation. The result of the analysis done in the software for bringing out the importance of digital cash is shown in the figure:

\section{Possible challenges}

Digital transactions happen in the digital space and government is facing a great challenge of locating the transaction. The government is lacking the understanding of the business model that the E-commerce firms are adopting which sometimes lead to imposition of tax under the title of "commission agents" which is contradictory to the prevailing FDI rule. The taxes are imposed at the point of delivery which amounting to double taxation as CST has been already collected on such goods. The government has to reframe the tax regulations in the country in order to identify the tax payers as well as the transactions which need to be taxed. 
The country is having physical presencebased permanent establishment rules which need to be amended so that place of business, location and permanency can be reconciled with new digital world. The following figure explains the challenges faced by the government in implementing the digital payment system.

As we know India is one of the country which has an economy which connects emotionally to the cash. The habbit of using cash is so intense in people that they don't want to use any other mode. And this is one of the reason why almost all E-Commerce site in India has a payment option "CashOn-Delivery". One of the reason why people opt for Cash on Delivery is their security concerns while some prefer to pay cash just as its their habbit. Indian population has this notion that cash is safe as many transactions will not be recorded and noone can track it. Use of cash on the other hand do not need the user to be educated while incase of digital payment system the user need to be literate. The providers need to design the system in such a way that it will be secured,safe and create a sense of familarity andlongevity for the same in the users.

Digitization of payments greatly depend on the business model adopt by the banks, businesses, telecom operators, retailers and other stakeholders. The acceptance of digital payments are very low at physical point of sales due to limited reach and acceptance of the same by merchants due to their fear. The acceptancy of merchants can be attained only by making them aware of the possible benefits they may derive from such transactions like they will not be facing any trouble in collecting money. Example: when a merchant uses card transactions when they have to receive Rs. 10.50 from a customer, he can exactly collect the same amount without loosing the paise, which he might have to discount in cash payment due to lack of change available with the merchant or the customer. The challenges faced by the customers in using the digital cash system are highlighted in the figure 9 given below:

\section{Suggestions and Conclusions}

The digital industry in India is going through a thrilling transition. Eventhough a large part of the economy which shifted to the digital payments there are still another large section which are averse towards the system. Industry drastically has earned a momentum but still $50 \%$ of the digital users find it complicated to use the system. Some find the security concerns while some are unaware about the remedies and other redressal proceedings incase they are cheated.

The suggestions this study recommends are:

Government should provide the necessary awareness to the people especially the rural population about the importance and need to digitalize payment system. This can be allocated to the village level officers who will have direct contact with the rural population and it can create a sense of security to the rural population to use the digital services.

There should be massive programs in urban as well as rural area to literate the people on the security measures and redressal programs. In case of any fradulent activities the people should know whom to approach and the grievence mechanism they should follow.

The threshold limit on cash transactions should be established strictly to reduce the blackmoney in the economy. The government should take necessary 
actions to encourage digital transactions by tax reliefs and the same should be communicated to the merchants.

The business models of banks should be restructured to adopt to digitization and digital players like FinTech companies should be encouraged to make more consumers use digital transactions where the company can remove or limit "Cash On Delivery" option.

Social media can be used as one of the major player to create awareness among the people about the importance of digital transaction. As Indians are in a need of corruption free nation, through social media it can be projected. When social benefits are transferred through bank accounts, there is a very limited choice for officials to abduct the money.

Tax reforms are another essential step to be taken by the Government as to collect the tax for digital transactions without imposing double tax or allowing evasion of tax. Transperancy is more in case of digital transactions and government need to decide where to tax, pouint of taxation, amount to be taxed for categories of commodities etc. A new rule need to be established for the digital space transactions for the welfare of the nation.

The smartphone penetration need to be more stronger and internet usage should be more widened. This can be done with the help of telecom operators of the nation as well as FinTech companies. FinTech companies with friendly apps can help government to spread digitization in more effective manner. Encourage these companies to spread awareness in the economy and government can provide them support like tax rebates or such benefits for doing such act.

The government of India with the help of digitization of payments will achieve less corruption in the country and a more financially inclusive economy. Jan Dhan Yojna had already helped the government to initiate people to open bank accounts, eventhough the accounts might be inactive with the scheme of Direct Benefit Transfer the social benefits as well as all government transactions will be made through accounts. In such a scenario accounts need to be activated and the economy need to access their bank accounts.

When the government put a threshold limit to the transactions that can be done with cash , all other transactions will automatically be through bank accounts. This create transperancy in the system. Tax evasion will no longer be a problem as each and every transactions will be recorded. Earlier what used to happen was when the government distributes some subsidies or relief fund it wouldn't reach the needed rather will be stuck up in the hands of government officials and other middlemen.when the government proposes to transfer it through bank accounts it will directly reach the beneficiaries.

With digitization India would become one among the many countries thriving towards digital cash economy. India might lead the countries globally in the digital space if the economy continues to adapt to the initiatives taken by the Government and other digital players. 
Fig.1

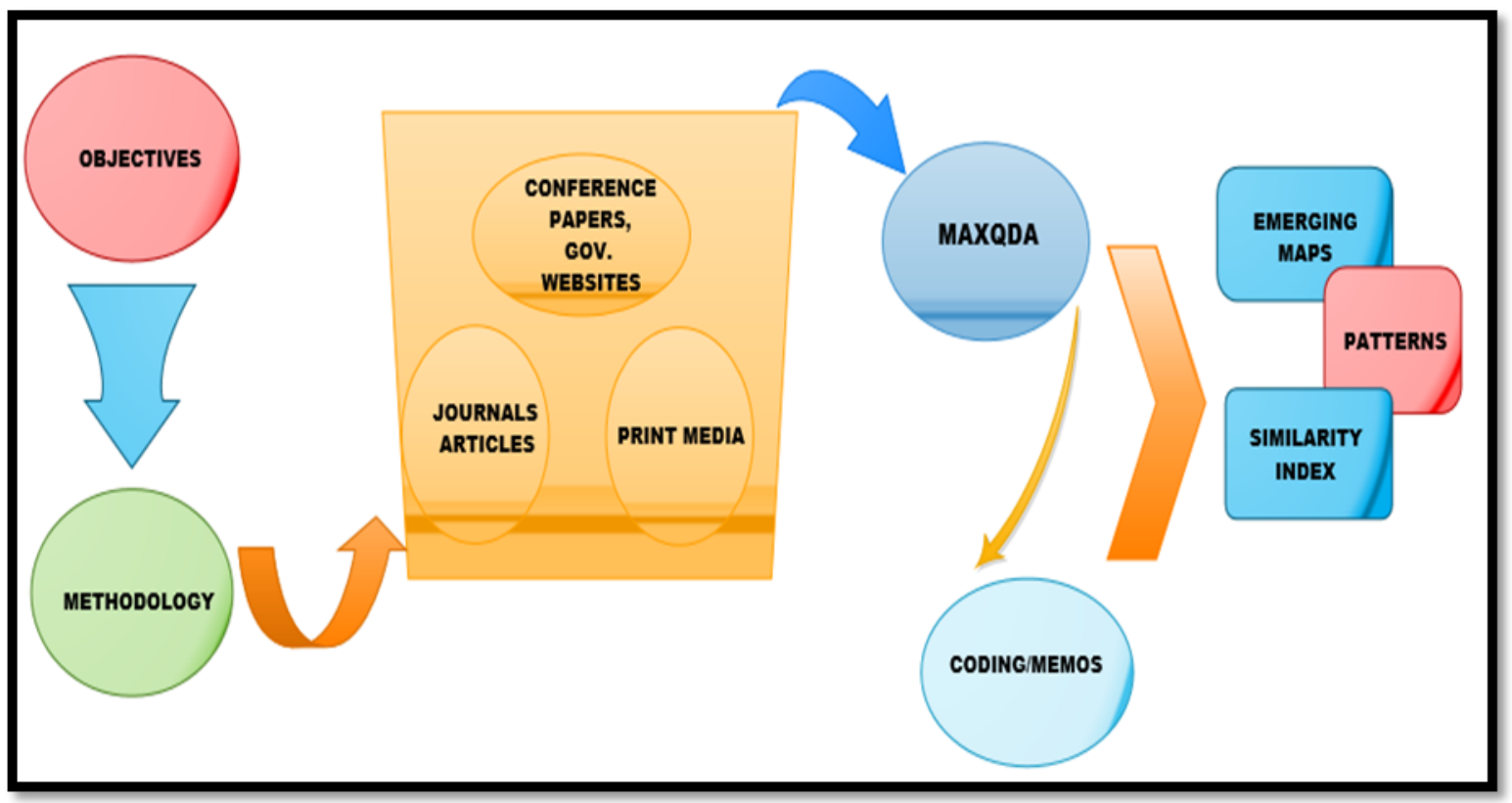

Fig.2

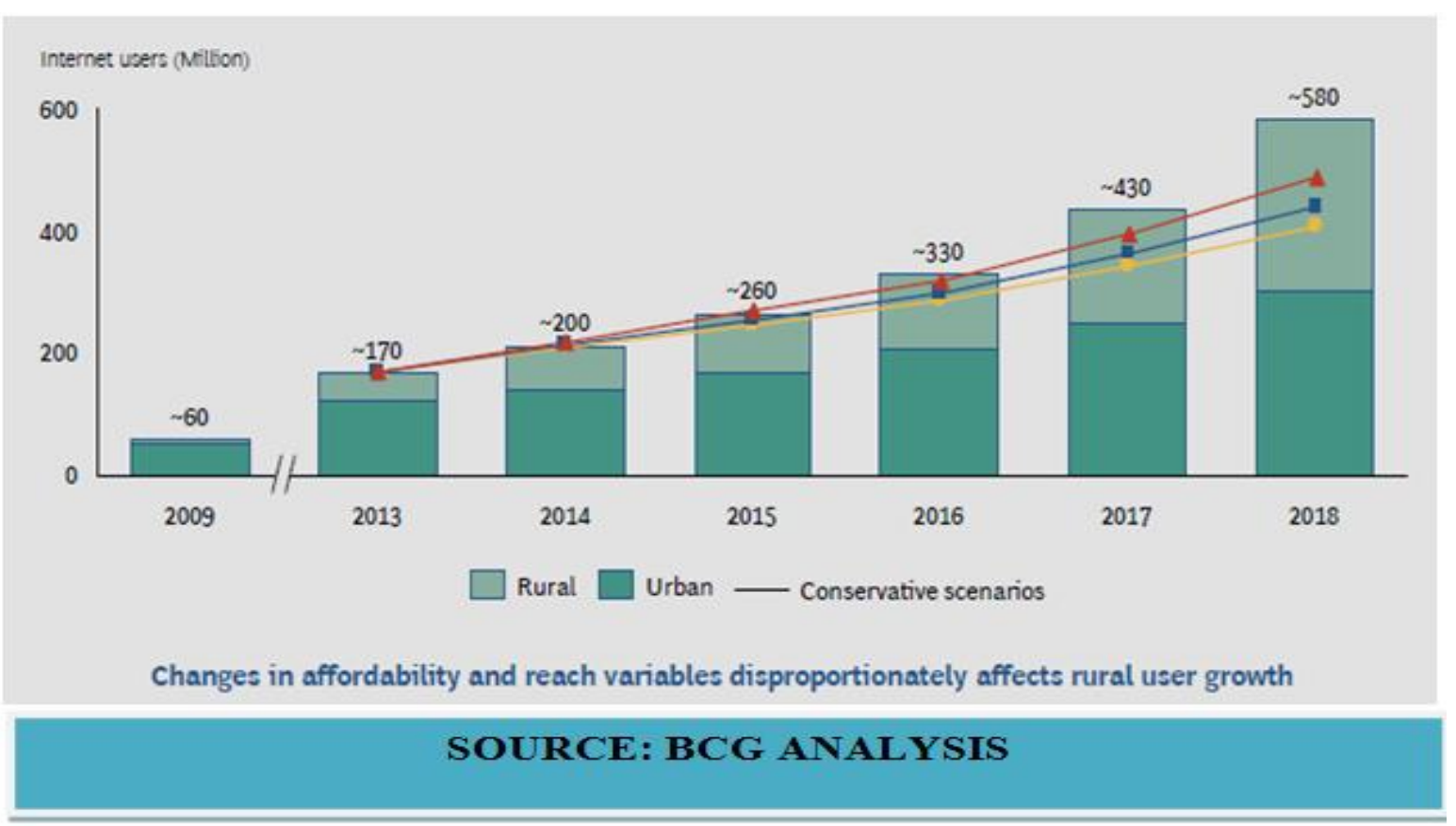




\section{Int.J.Curr.Res.Aca.Rev.2016; 4(12): 8-26}

Fig.3

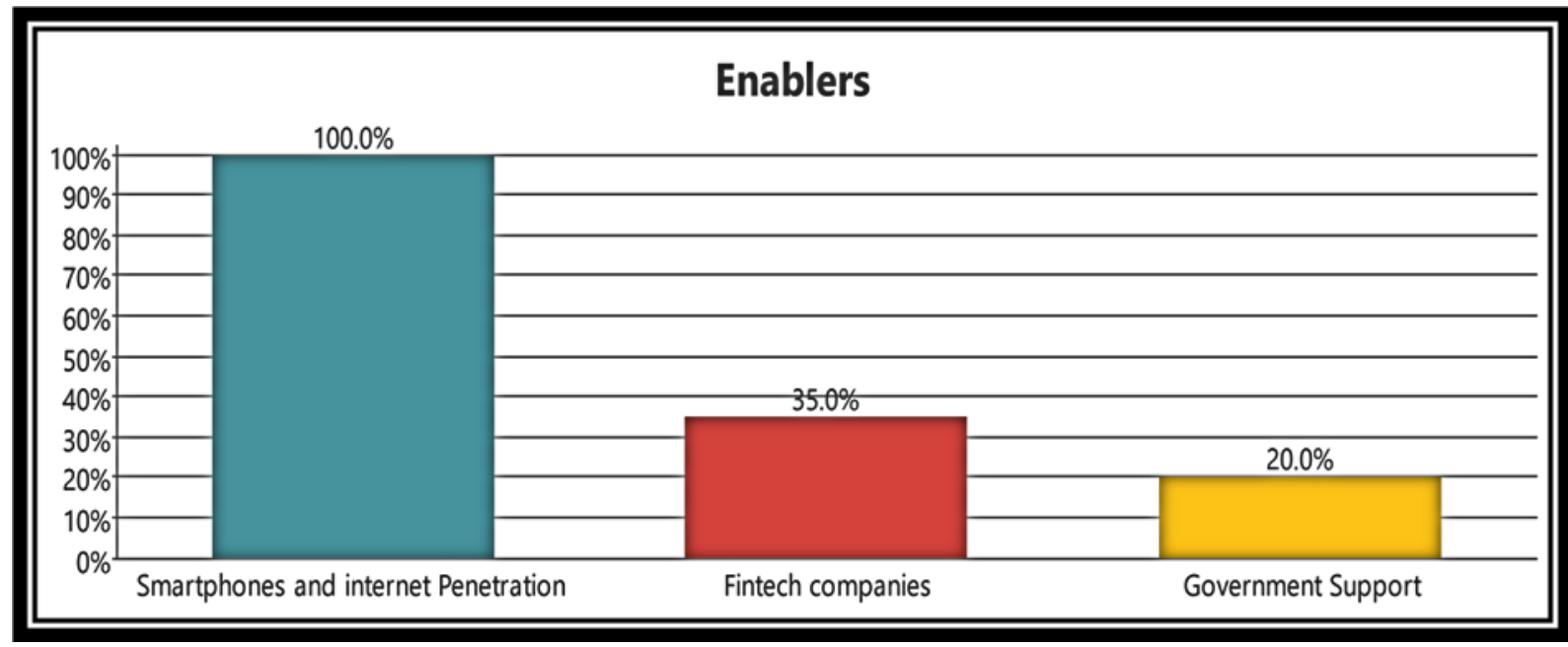

Fig.4

\section{Measures by government}

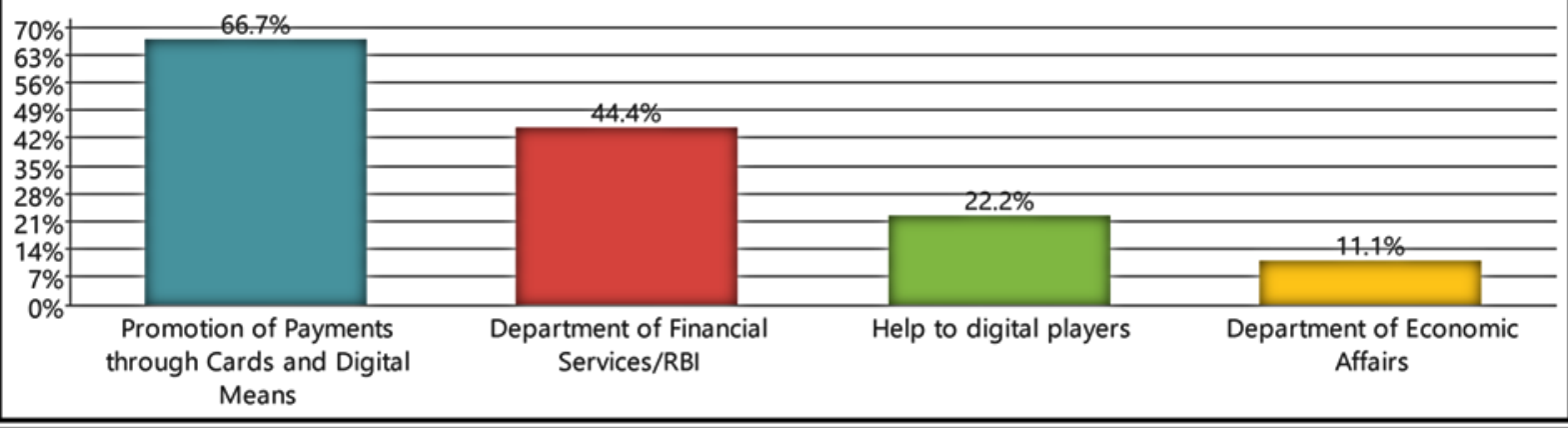

Fig.5

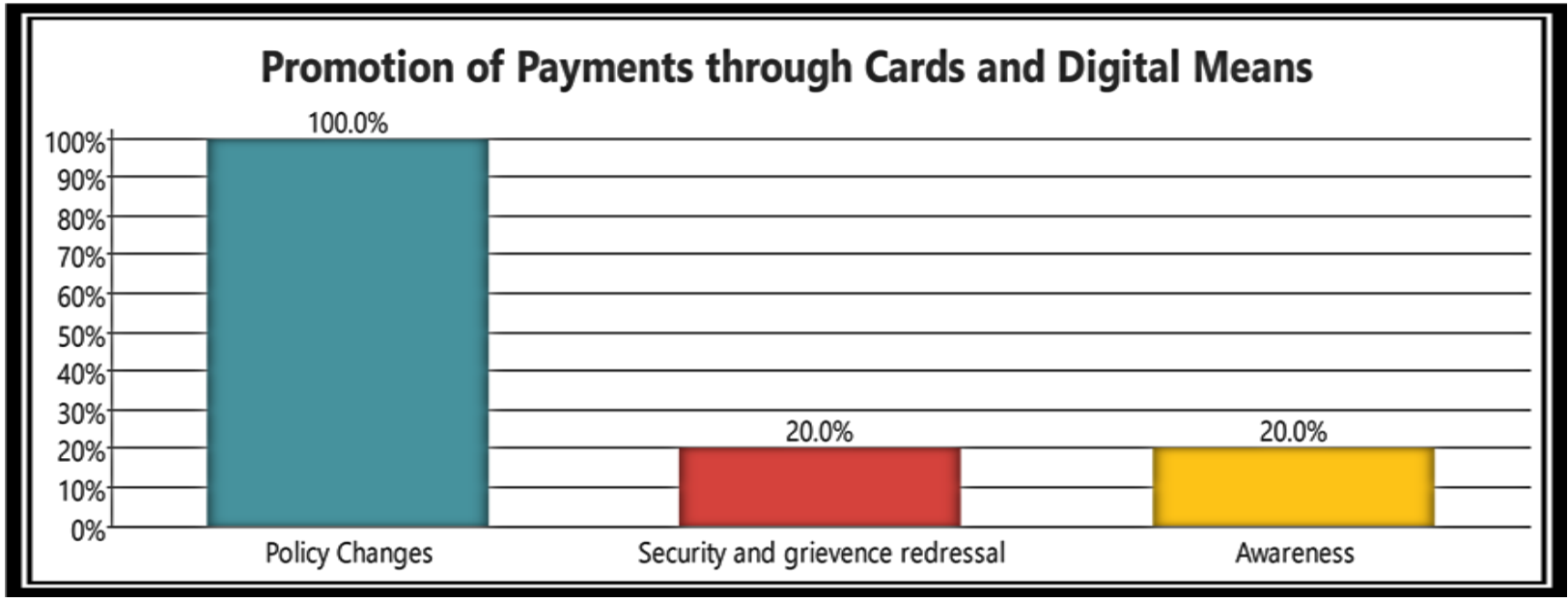


Int.J.Curr.Res.Aca.Rev.2016; 4(12): 8-26

Fig.6

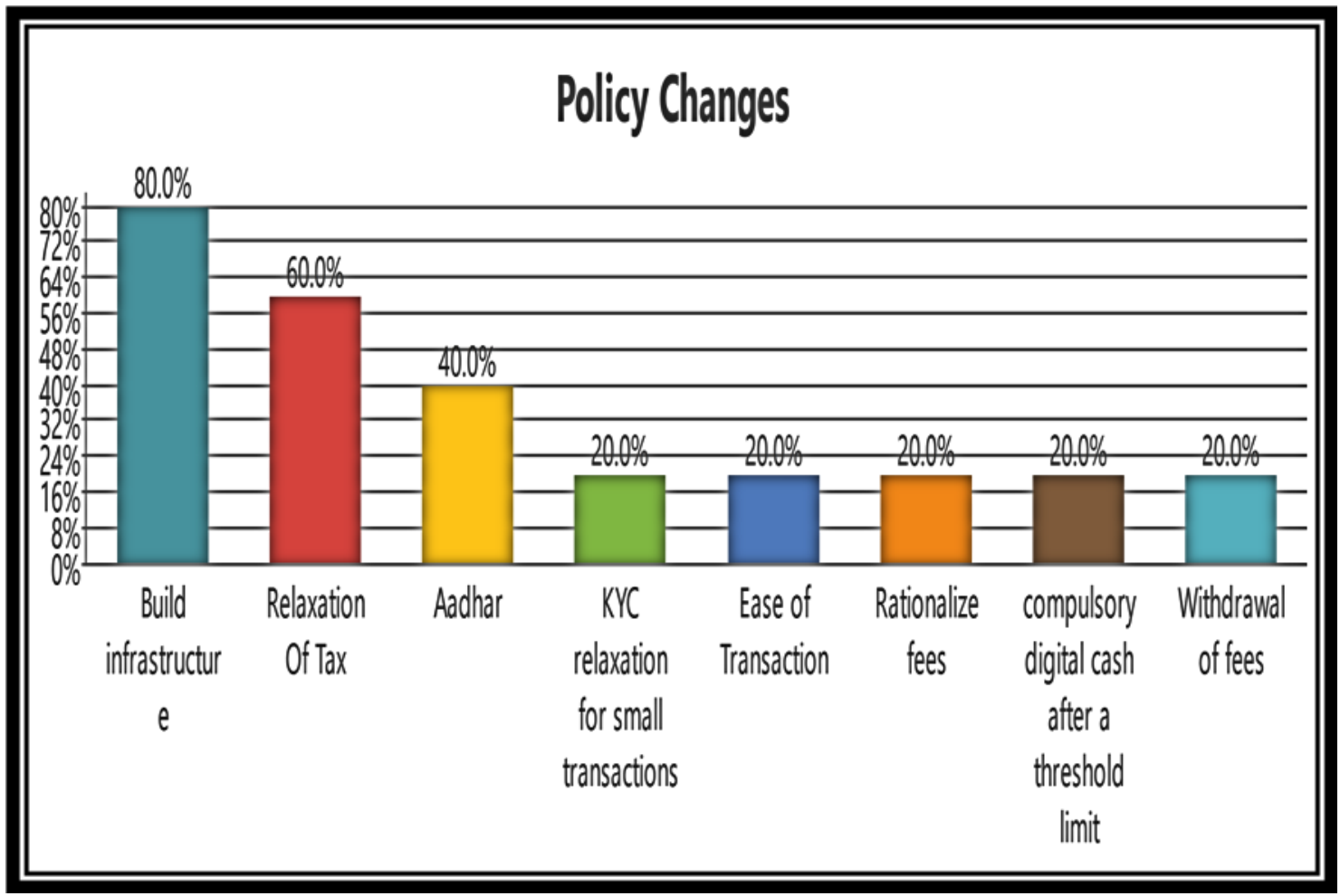

Fig.7

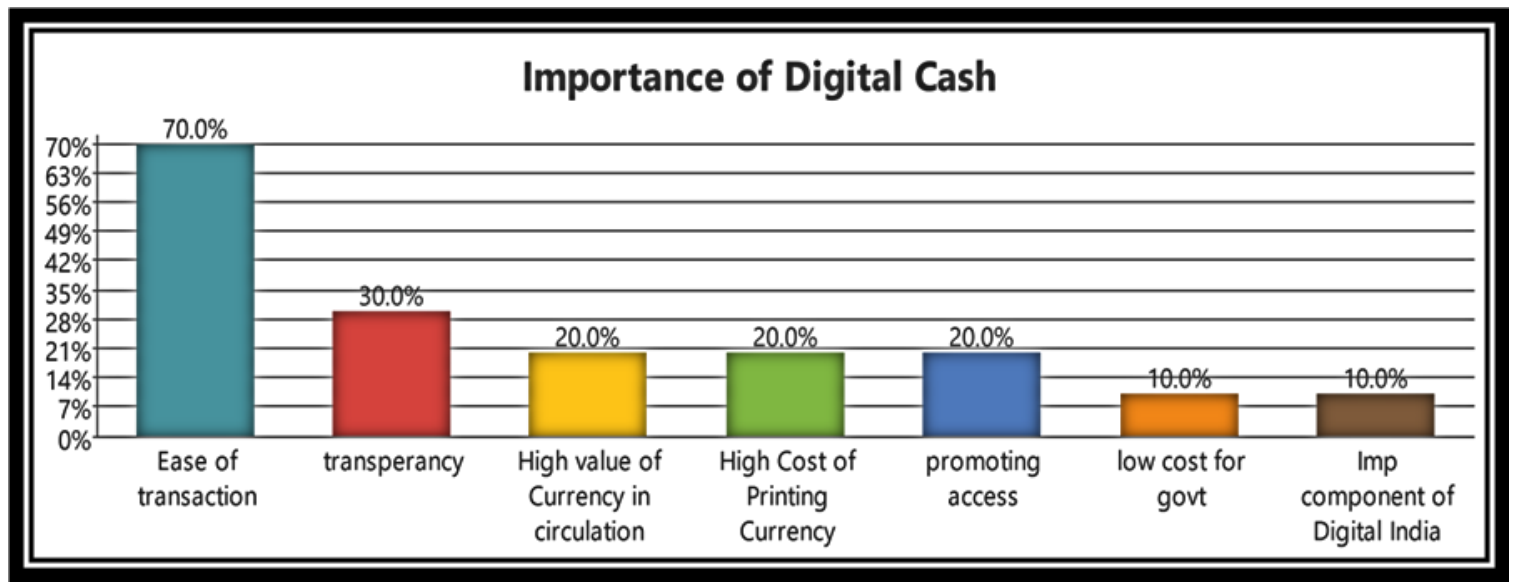




\section{Int.J.Curr.Res.Aca.Rev.2016; 4(12): 8-26}

\section{Fig.8}

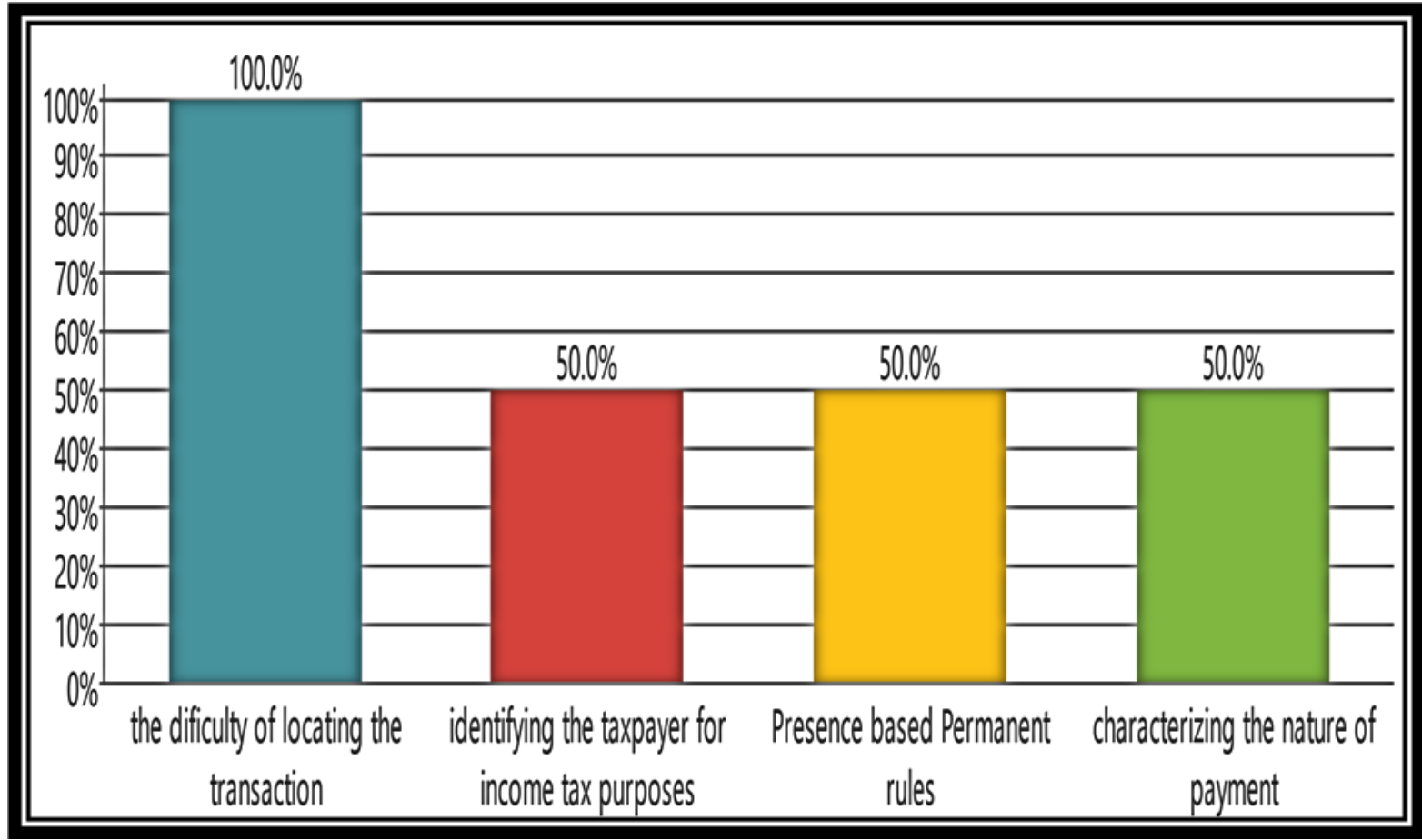

Fig.9

\section{Challenges - customers}

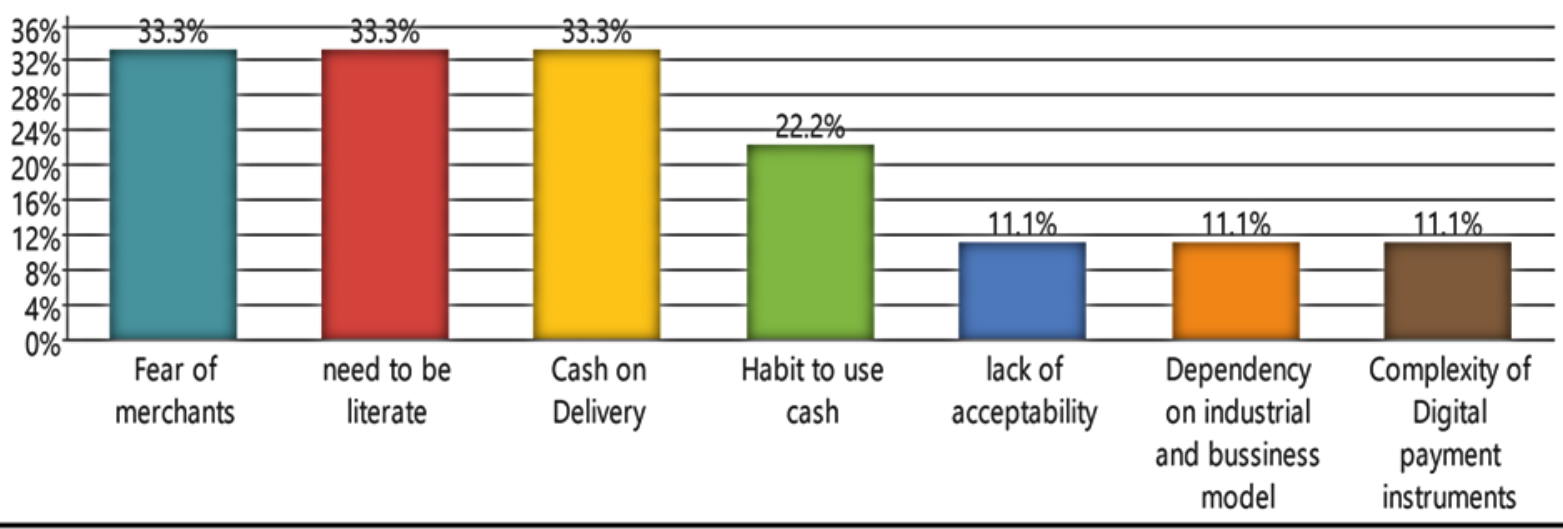




\section{Pic.1}

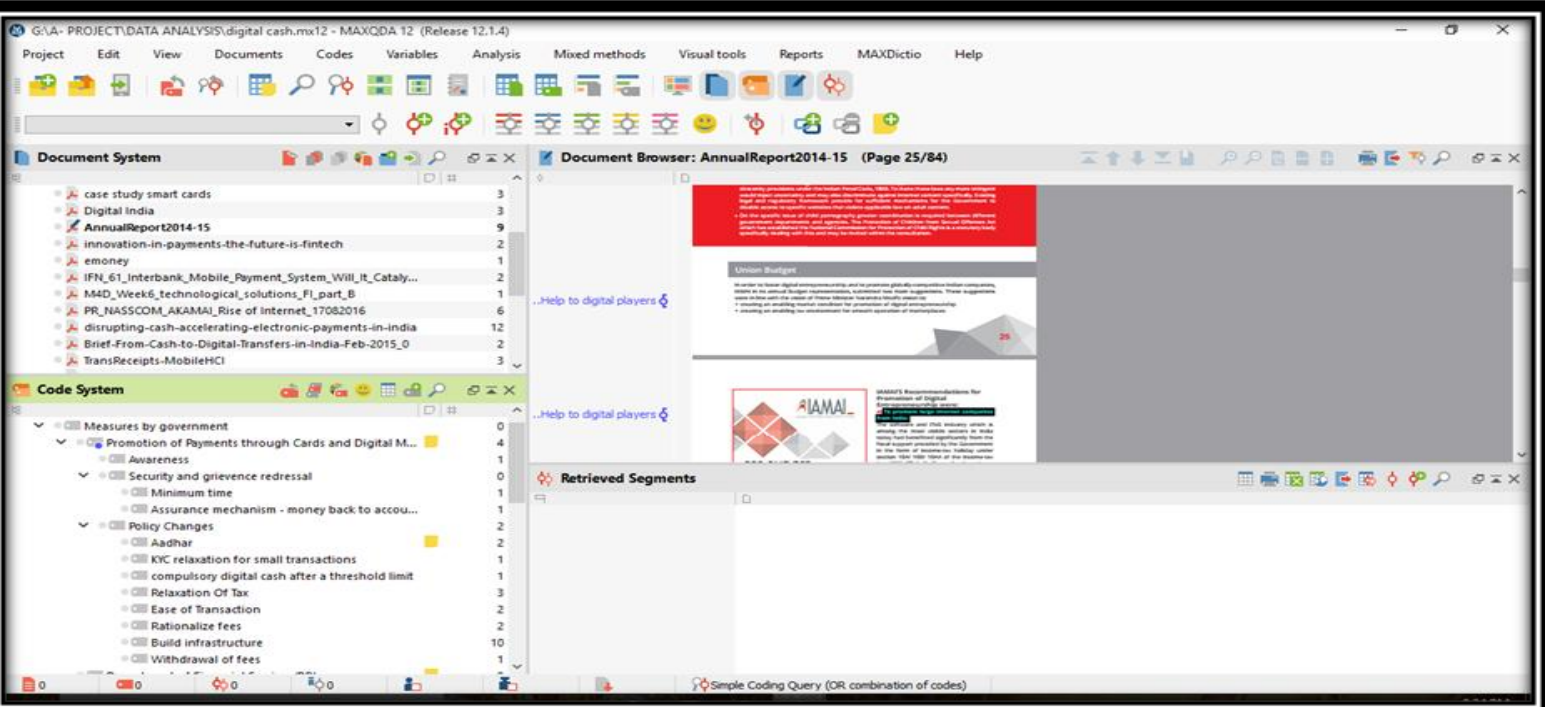

Pic.2

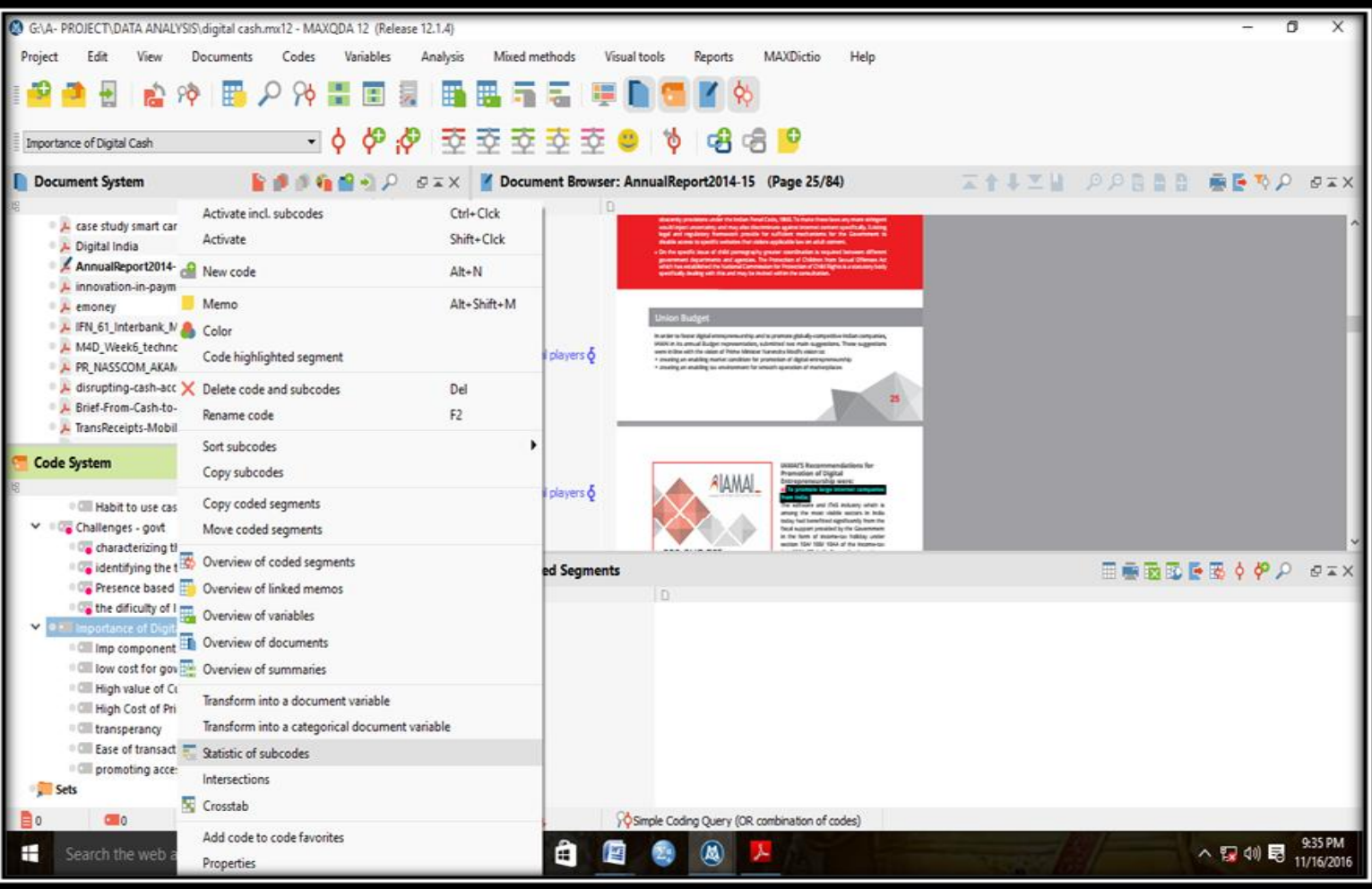


Pic.3

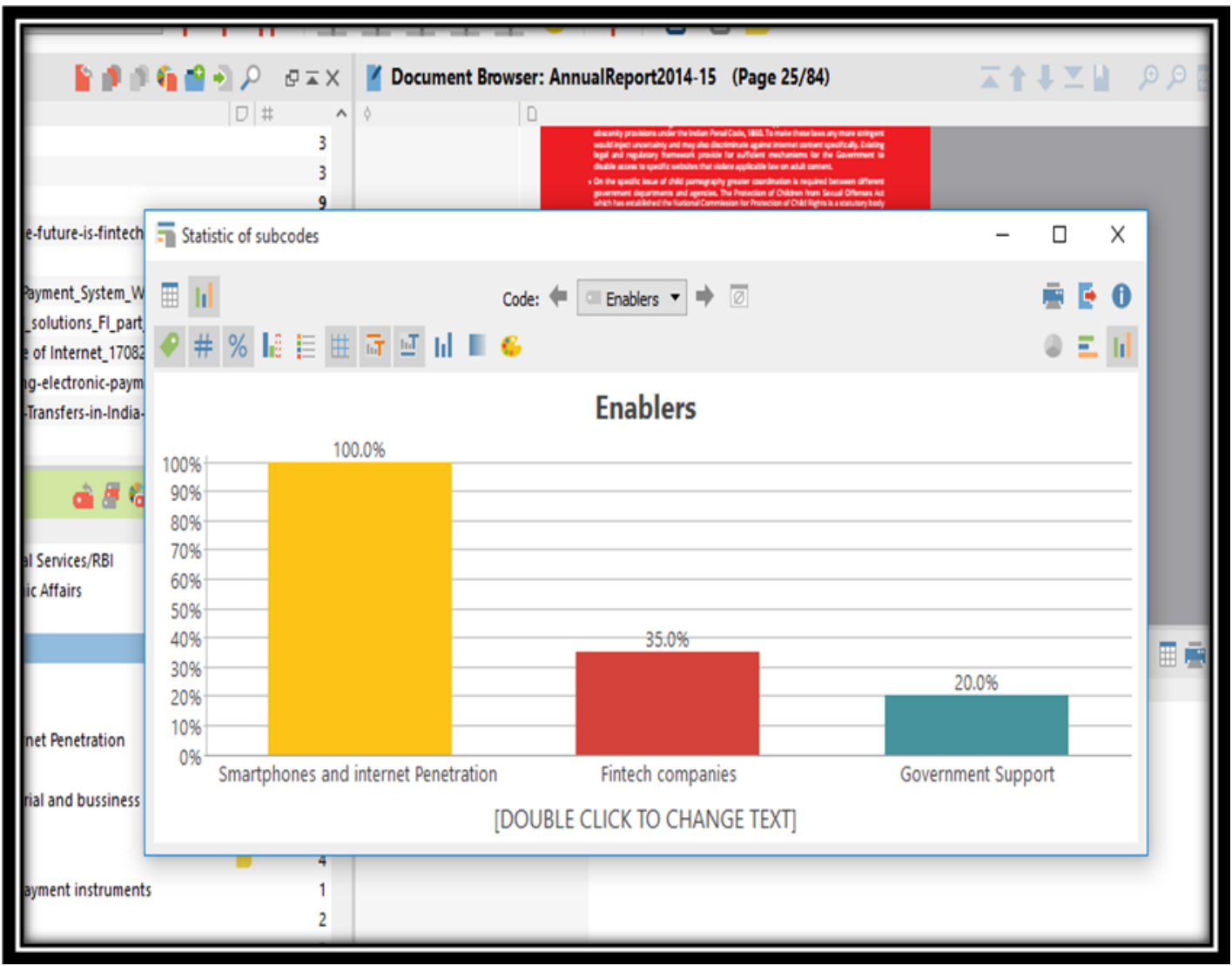

India has the potential to become fisrt digital economy as it has more youngsters andtech savvy population. The strength of the nation is young population and their adaptability and openness towards innovation. This economy hand in hand with government will lead India towards "Digital India".

\section{Acknowledgements}

I sincerely thank my parents for their blessings and prayers without which this study wouldn't have been possible. I thank my guide Prof. Radha Kumari for all the guidance and constant supervision as well as for providing necessary information regarding the project $\&$ also for their support in completing the project. I am indebted to the Director of the campus Prof. Madhu Kapani for all the support she has extended and to all the teachers who had supported me in this venture. I would like to express my gratitude towards my classmates for their kind co-operation and encouragement which help me in completion of this project. I extend my thanks to the warden of the hostel Dr. Kiron Bala Arora, warden, Ms. Meera, incharge of EB2 hostel for making arrangement for conveniently working for the project. I extend my sincere gratitude and thanks to my beloved Lord Bhagwan Sri Sathya Sai Baba for working through me with unseen hand in all my endeavours.

\section{References}

Baidya, A. 2015. http://dazeinfo.com. Retrieved June 25, 2016, from Dazeinfo: http://dazeinfo.com/2015/09/ 
04/number-mobile-phone-subscribersindia-q2-2015-growth-airtel-vodafonebsnl-broadband-trai/

Banerjee, B. (n.d.). Mobile Wallet Payments - The Next Big Wave in India. India: Game changers - Ipsos.

Banerjee, S.S. 2015. From Cash To Digital Transfers in India:The Story So Far. Washington,DC: CGAP.

Bill \& Melinda Gates Foundation. (2014). Digitizing Government Payments in Nigeria, United States: Bill \& Melinda Gates Foundation.

Chandarana, N. 2015. Payment Bank - A Need of Digital India. Abhinav National Monthly Refereed J. Res. Commerce \& Management, Volume 4, Issue 11.

Choudhury, V. 2016. iamwire.com. Retrieved June 23, 2016, from iamwire:

http://www.iamwire.com/2016/03/mo

bile-internet-penetration-india-2016-

rural-urban $/ 133328$

Chuen, D.K., \& Teo, E.G. (n.d.). Emergence of Fintech and The Lasic Principles.

Department of Electronics \& Information Technology,Government of India. 2015. Digital India Programme. Retrieved June 10, 2016, from digitalindia.gov.in:

http://www.digitalindia.gov.in/

Dowd, K. 1998. Monetary policy in the 21st century:An impossible task? Cato J., vol. 17 , no:3.

Economic Times. 2006. FinTech 100 ranks Wipro among the top 25. India: Economic Times.

Eko. 2007. Eko.co. Retrieved June 2016, from Eko Financial Solutions Ltd: http://eko.co.in/

Extravelmoney. 2014. extravelmoney.com. Retrieved June 02, 2016, from Extravelmoney: www.extravelmoney.com
Eyers, J. 2015. Stone \& Chalk names fintech hub's resident start-ups. Australian Financial Review, 17.

Godschalk, H., \& Krueger, M. 2000. Why E-money still fails- chance of emoney within competitive payment instrument market.

Godschalk, H., \& Krueger, M. 2000. Why emoney still fails. Berlin: Third Berlin Internet Economics Workshop.

Government of India Ministry of Finance. 2016. Office memorandum, New Delhi: Department of Economic Affairs Currency \& Coinage Division.

Hayashi, Y. 2015. Fintech a revolution in the world of finance. My Vision.

Johnson, D. 2008. Use of Smartcards to Deliver Government Benefits in Andhra Pradesh. Andhra Pradesh: Institute for Financial Management and Research.

Kaur, R., \& Kaur, R. 2015. Current And Future Scenario Of E -Payment System In India. Int. J. Business Management, ISSN NO. 2349-3402 VOL. 2(1).

Kleiner, A., English, E., Siboni, G., Sarin, A., Ranganathan, K., Bajaj, K., et al. 2015. Digital Debates 2015. CyFy J., Volume 2.

Maheshwari, R. 2016. AV Birla's More to accept Paytm wallet payment. Retrieved Feb 29, 2016, from economictimes.indiatimes:

http://economictimes.indiatimes.com/i ndustry/services/retail/av-birlas-moreto-accept-paytm-walletpayment/articleshow/51102044.cms

Maras, E. 2016. India moving a billion people into digital finance. Retrieved feb 22, 2016, from fintechranking.com: http://fintechranking.com/2016/02/15/i ndia-moving-a-billion-people-intodigital-finance/ 
Matonis, J.W. (n.d.). Digital Cash And Monetary Freedom. Economic Notes.

McKinsey Global Institute. 2016. Digital finance for all:powering inclusive growth in emerging economies. McKinsey\&Company.

Nasscom - AKAMAI Technologies. 2016. How internet is changing India - one connection at a time. New Delhi: Nasscom - AKAMAI Technologies.

Paytm. 2010. paytm.com. Retrieved June 05, 2016, from Paytm: https://paytm.com/about-us/

Rao, S.S. 2005. Bridging digital divide:Efforts In India. Telematics and Information, 361-375.

Rathore, D.H. 2016. Adoption of digital wallet by consumers. BVIMSR's J. Management Res., Vol. 8 Issue - 1.

Sadana, M., \& Wright, G.A. 2011. Interbank Mobile Payment System: Will It Catalyse Financial Inclusion? India: MicroSave India Focus.

Santomero, A.M., \& Seater, J.J. 1996. Alternative monies and the demand for media of exchange. J. Money, Credit and Banking, vol.28, no:21, part b, 942960.

Shah, A., Jain, N., \& Bajpai, S. 2015. India@Digital Bharath. Delhi: Bonston Consultancy Group.

Shah, A., Jain, N., \& Bajpai, S. 2015. India@digital.baharth. Mumbai: The Boston Consultancy Group, Internet And Mobile Association Of India.

Shukla, P.T. 2016. Mobile wallet: present and the future. Int. J. Multidisciplinary and Academic Res., Vol. 5, No. 3, June 2016 (ISSN 2278 - 5973).
Singh, R. 2015. Leveraging Technology and More: Case for a less Cash Economy. India: IFMR LEAD.

Surya, N. 2016. moneycontrol.com/news. Retrieved Oct 16, 2016, from Money Control:

http://www.moneycontrol.com/news/e conomy/budget-2016-time-to-makedigital-cash-play-game-changer-fordigital-india_5547521.html

The Internet and Mobile Association of India. 2014-15. 11th Annual Report. INDIA: IAMAI.

UK Government Chief Executive Advisor. 2015. Fintech Futures, The UK as a world leader in financial technologies. UK: UK Government.

Varshney, R. 2016. computer.financialexpress.com.

Retrieved June 20, 2016, from Express Computer:

http://computer.financialexpress.com/f eatures/budget-2016-incentives-fordigital-payment-for-financialinclusion/16076/

Vasava. 2015. The Fintech Revolution. London Business School Review, 5053.

Vishwanathan, V. 2015. Fintech: redefining money transactions. Retrieved feb 13, 2016, from livemint.com: http://www.livemint.com/Money/qFe9 8IF7j5NR5sKXXrrJRK/Fintechredefining-money-transactions.html

World Bank Development Research Group, the Better Than Cash Alliance, and the Bill \& Melinda Gates Foundation. 2014. The opportunities of digitizing payments, Australia: G20 Australian Presidency.

\section{How to cite this article:}

Smrithi Baiju and Radhakumari Challa. 2016. Digitisation of Payments - A Step towards Digital India Movement. Int.J.Curr.Res.Aca.Rev.4(12): 8-26.

doi: http://dx.doi.org/10.20546/ijcrar.2016.412.002 